the preparation of new redactions and translations, with full critiques, was an urgent task; the training of archaeologists from east and central Africa should be given a high priority; the conference should be reconvened in four years with further participation of scholars from the countries concerned.

The proceedings of the conference will be published during 1968.

\title{
Recherches socio-économiques en zone arachidière sénégalaise
}

UNE mission interdisciplinaire de quatre chercheurs appartenant à l'Office de la Recherche Scientifique et Technique Outre-Mer (ORSTOM) va étudier pendant plus d'un an (mars I967 à juin 1968) les comportements économiques et la situation socio-culturelle dans la zone arachidière du Sénégal. Patronnée par MM. les Professeurs Balandier, Nicolai et Perrin, cette mission se compose de deux économistes, MM. Ph. Couty et J.-M. Gastellu, d'un sociologue, M.-J. Copans et d'un psychosociologue, M.-B. Delpech.

La culture de l'arachide est prépondérante dans l'économie sénégalaise. Un système coopératif de commercialisation et de prêts en matériel agricole et en semences encadre les producteurs villageois. En outre, l'emprise de la confrérie musulmane des Mourides se manifeste très fortement, surtout chez les Wolof. Un échantillon de plusieurs villages a été choisi de manière à déterminer des cadres différents, mais significatifs des comportements économiques. Trois villages Wolof et Mourides ont été retenus, de taille différente, et où le fonctionnement des coopératives rencontre des conditions plus ou moins favorables. L'un de ces trois villages est habité par des Baye Fall, groupe mouride où l'encadrement et l'autorité maraboutiques s'exercent de façon particulièrement stricte. Le quatrième village est Sérère, en partie christianisé. Un élément d'intérêt supplémentaire est fourni par la situation économique consécutive à la mauvaise récolte de fin 1966. Les conséquences économiques et sociologiques de cette situation exceptionnelle (la commercialisation par les coopératives a été presque nulle) rendront fructueuse la comparaison avec l'année 1967 , qui sera certainement meilleure. L'enquête s'échelonnant sur deux périodes de traite, les résultats ne seront pas trop affectés par cette circonstance particulière.

Le terme de mission interdisciplinaire mérite d'être précisé. Il implique en effet une forme particulière de collaboration entre des chercheurs de disciplines différentes, bien qu'apparentées. Attribuer un village à chaque chercheur, que celui-ci eût étudié selon ses techniques personnelles, eût abouti à un déséquilibre et à une inadéquation entre les diverses masses d'information. D'autre part, l'étude systématique de chaque village par l'ensemble des quatre chercheurs était exclue pour des raisons pratiques: difficultés d'implantation, durée de l'enquête.... Une solution moyenne a donc été dégagée, au moins provisoirement: deux groupes composés d'un économiste et d'un sociologue (ou psychosociologue) se répartissent deux villages chacun. Ce découpage témoigne que chaque chercheur entend personnellement dépasser, si besoin est, les limites que la tradition universitaire assigne à sa discipline d'origine. L'accord une fois établi sur les grands thèmes de recherche, chacun en élabore une partie, même s'il doit recourir aux techniques de la discipline voisine. Ainsi est garantie l'homogénéité des résultats, ce qui est fondamental dans une enquête de ce genre.

Au delà de cette articulation simple en deux équipes, il convient d'insister sur les thèmes propres à chaque discipline, qu'ils aient été définis d'après les particularités du terrain choisi ou dans le cadre de techerches personnelles. Ainsi, les économistes s'intéressent plus particulièrement aux problèmes de revenu et d'épargne, à la rentabilité de l'équipement et au fonctionnement des coopératives. Le sociologue étudie la stratification sociale et le tôle joué par certains individus-clés (marabouts, présidents de coopératives). Le psychosociologue, utilisant les techniques classiques de sa spécialité, s'attache aux problèmes soulevés par des mentalités religieuses spécifiques. 
Ainsi devraient pouvoir être précisées les incidences du système coopératif et de l'idéologie mouride sur la vie économique quotidienne, au niveau du village et des groupes sociaux. La fonction de groupes ou d'individus spécifiques dans le développement des diverses spéculations agricoles devrait également être mise en lumière. Enfin, l'analyse du système coopératif et du rôle de la SATEC (Société de mise en valeur agricole) contribuera à l'étude des facteurs de développement dans le cadre d'une culture commerciale.

\section{University of Sussex: School of African and Asian Studies}

The School of African and Asian Studies at Sussex (Dean: Professor D. A. Low; Sub-Dean: Dr. D. P. J. Wood) opened in 1964 and there are now 120 undergraduates, 55 of them in the first year, and 55 postgraduates. For the B.A. degree undergraduates take courses in an established academic discipline in which only a limited amount of special attention is given to African and Asian issues. They also take four ' contextual ' courses oriented to Africa and Asia, several of which are of an interdisciplinary nature. Post-graduates work either for the one-year course degree (M.A.) or for one of the research degrees (M.Phil., D.Phil.). There are M.A.s in Development Economics, in African Studies, and in Politics, International Relations, History, and Geography, with special emphasis on Africa. There is also a two-year dissertation degree (M.Phil.) in Social Anthropology. In all these fields research degrees may also be taken. (Inquiries about these courses should be sent to the Director of Graduates (Arts and Social Studies), University of Sussex, Falmer, Brighton, Sussex.) The School is closely associated with the Institute of Development Studies at the University (Director: Professor Dudley Seers) which has recently been established by the Ministry of Overseas Development. Fellows of the Institute hold titular posts within the University, while research students of the Institute take research degrees of the University. (Inquiries should be addressed to the Secretary, Institute of Development Studies, Stammer House, Brighton.) Teaching in African languages is due to be developed shortly. Under the cooperative scheme organized by the Standing Conference on Library Materials relating to Africa the Sussex University Library is building up a major collection on East Africa. The Institute of Development Studies is forming a substantial library collection as well on all aspects of development overseas. Recently the School received a generous grant of $\$ 150,000$ from the Rockefeller Foundation. Together with some assistance from the Ministry of Overseas Development this will enable it to second faculty members for teaching and research purposes to a number of universities in Africa and elsewhere. The School has chosen East and Central Africa and Nigeria for special attention in Tropical Africa.

\section{Linguistic Courses and Research at the University of Ibadan}

THE Department of Linguistics and Nigerian Languages of the University of Ibadan offers a programme of linguistic research and teaching with special emphasis upon West African languages. Members of the staff are currently conducting research on Yoruba, Hausa, and Igbo; Isoko and languages of the Edo group; Pidgin; Ijo; Higi, Margi, Bura, and other Chadic languages; Ngwe; Mbe; and Kambari. There is also an interest in comparative and historical studies, contrastive analysis, and the teaching of English as a second language. The Department has a well-equipped laboratory suitable for phonetic research.

Degree courses in Yoruba and Linguistics are available as well as subsidiary courses in Hausa, Yoruba, and Linguistics. For graduates, there are programmes leading to the PostGraduate Diploma in Phonetics and Linguistics (one year), the M.A. degree (two years), and the $\mathrm{Ph} . \mathrm{D}$. degree (three years). All these programmes require original research in addition to course work. Opportunities for research are abundant, since many languages 